Acta. vet. scand. 1976, 17, 101-106.

From the Department of Physiology, Endocrinology and Bloodgrouping, Royal Veterinary and Agricultural University, Copenhagen, Denmark.

\title{
THE ZINC-MYOGLOBIN RELATIONSHIPS IN PORCINE MUSCLES
}

\author{
By \\ $P$. Fogd Jørgensen and Inger Wegger
}

JØRGENSEN, P. FOGD and INGER WEGGER: The zinc-myoglobin relationships in porcine muscles. Acta vet. scand. 1976, 17, 101-106. - Zinc and myoglobin content in muscles from pigs were studied under various conditions. Zinc concentration was considerably higher in red than in white muscles. In muscles, where the metabolic pattern changes from glycolytic to oxidative during the period from birth to weaning, a simultaneous increase in zinc content was seen. A significant positive correlation exists between myoglobin and zinc content under normal conditions. However, while myoglobin concentration decreases due to iron deficiency anaemia no changes occur in zinc content. It is concluded that no functional link seems to exist between zinc metabolism and myoglobin synthesis in porcine muscles.

zinc; myoglobin; muscle; iron deficiency; pig.

Zinc has long been known to influence muscle function in vitro (Sandow \& Bien 1962), however, the role of zinc for the metabolism and function of muscles in vivo still remains to be clarified. The fact that zinc depletion does not alter muscle zinc concentration (Cassens et al. 1963) indicates partly that this trace element is firmly bound in muscle partly that the maintenance of normal zinc content is of essential importance for the function of muscle tissue. The muscle zinc pool can hardly be considered to have any depot function. Experiments with ${ }^{65} \mathrm{Zn}$ (Miller et al. 1967, 1970) have shown that muscle tissue continues to accumulate ${ }^{65} \mathrm{Zn}$ for several weeks following oral administration of the isotope, thus indicating a very low turnover rate. Furthermore, the accumulation rate seems to vary according to muscle type (Cassens et al. 1967). 


\section{MATERIALS AND METHODS}

Five litters comprising a total of 36 pigs were used to study the changes in muscle zinc content from birth to weaning. The pigs were reared either by normal or by zinc deficient dams. Two pigs from each litter were sacrificed immediately after birth, and at different time intervals thereafter 1 pig from each litter was killed. Myoglobin and zinc content in different muscles was estimated in 10 normal pigs aged 5 months. The influence of iron deficiency anaemia on myoglobin and zinc content in muscles was studied in 6 pigs (littermates) 3 of which got 150 $\mathrm{mg} \mathrm{Fe}$ (as dextran-Fe) s.c. on day 3 of life and a further dose of $100 \mathrm{mg} \mathrm{Fe}$ at the age of 4 weeks. The remaining 3 pigs received no iron supplementation, 1 of these pigs died before the experiment was terminated and is not included in the material. The other 5 animals were sacrificed when they were 6 weeks old.

Myoglobin was determined as described by de Duve (1948) with certain modifications. Zinc was estimated by means of atomic absorption spectrophotometry following acid digestion of muscle tissue (Kristiansen et al. 1971).

\section{RESULTS AND DISCUSSION}

In accordance with earlier investigations by Cassens et al. (1963, 1967) the zinc content in skeletal muscles from pigs was found to vary with the type of the muscle. The zinc concentration being by far highest in typical red muscles ( $m$. flexor dig. ped. sup.) and lowest in typical white muscles (m. longis. dorsi), while mixed type muscles had intermediary levels of zinc content as shown in Fig. 1.

Concomitant with these results is the increase in zinc concentration from birth to weaning in muscles such as $\mathrm{m}$. flexor dig. ped. sup. where the metabolic pattern changes from glycolytic to predominantly oxidative during this period of time. On the other hand, no changes in zinc content occur in m. longis. dorsi where the glycolytic pathway continues to dominate the metabolism (Fig. 2). No differences in muscle zinc content were found between normal and zinc depleted piglets, hence, the values shown in Fig. 2 are averages of results from both groups.

As could be expected from these results, a significant positive correlation ( $\mathrm{P}=\mathbf{0 . 0 0 0 1}$ ) exists between zinc and myoglobin content in the muscles taken as a whole (Fig. 1). However, within 


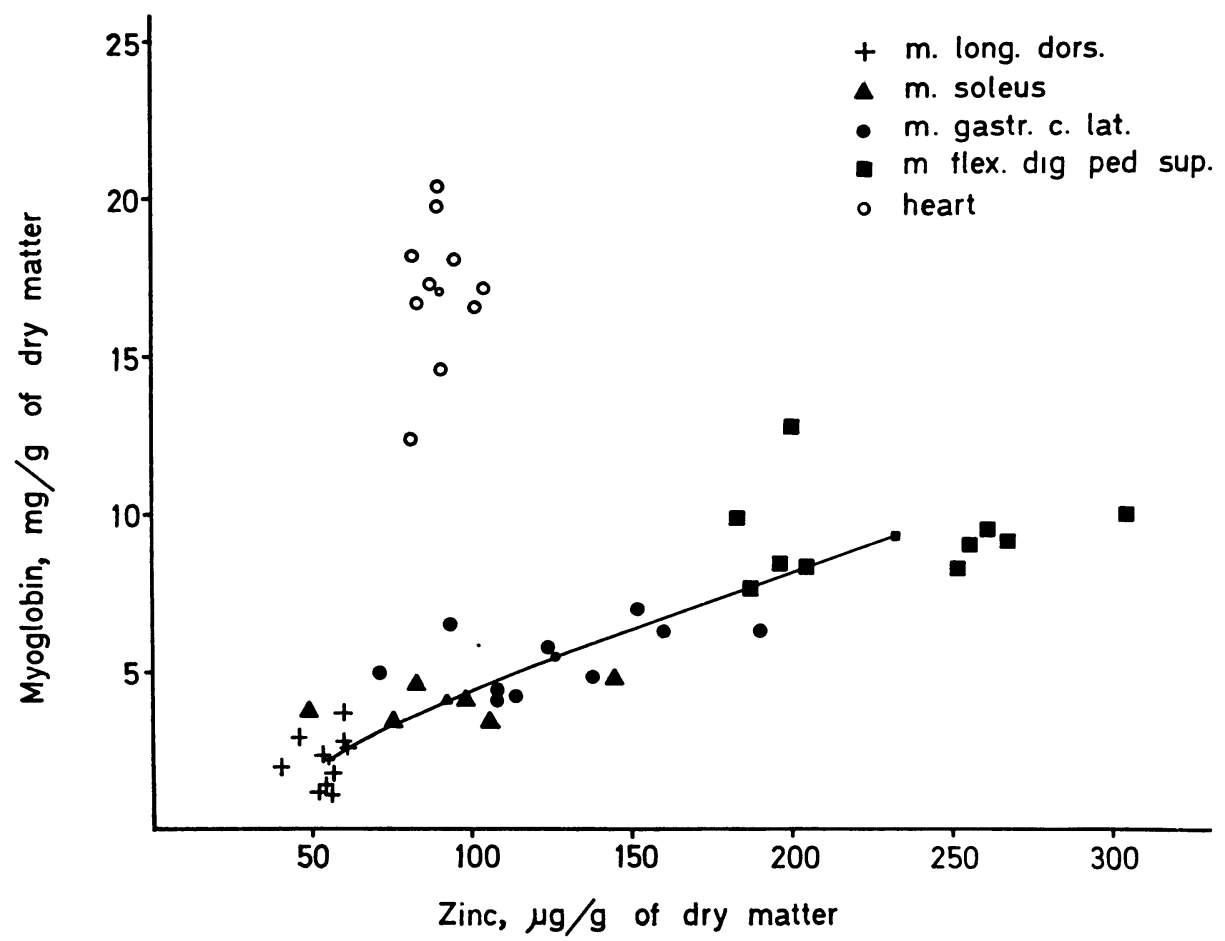

Figure 1. The relationships between zinc and myoglobin content in 4 skeletal muscles and heart. Average values for each muscle are shown by small symbols.

the individual muscle the correlation was not significant presumably due to the limited number of animals studied. Heart tissue differs in several ways from striated muscles. Irrespective of the very high myoglobin content the zinc concentration is of the same order of magnitude as in for example m. gastrocnemius, a mixed type muscle (Fig. 1) and the concentration is constant from birth to weaning (Fig. 2).

Whether the relation between zinc and myoglobin is of functional importance or not is difficult to estimate. The fact that myoglobin content of muscle is unchanged during zinc deficiency (Henry \& Bratzler 1960) is of no significance in this connection since the zinc concentration also remains unaffected, as shown by Cassens et al. (1963) and confirmed by the present investigations. In an attempt to elucidate if variations in myoglobin concentration are paralleled by changes in zinc content both compounds were estimated in muscles from normal and anaemic 


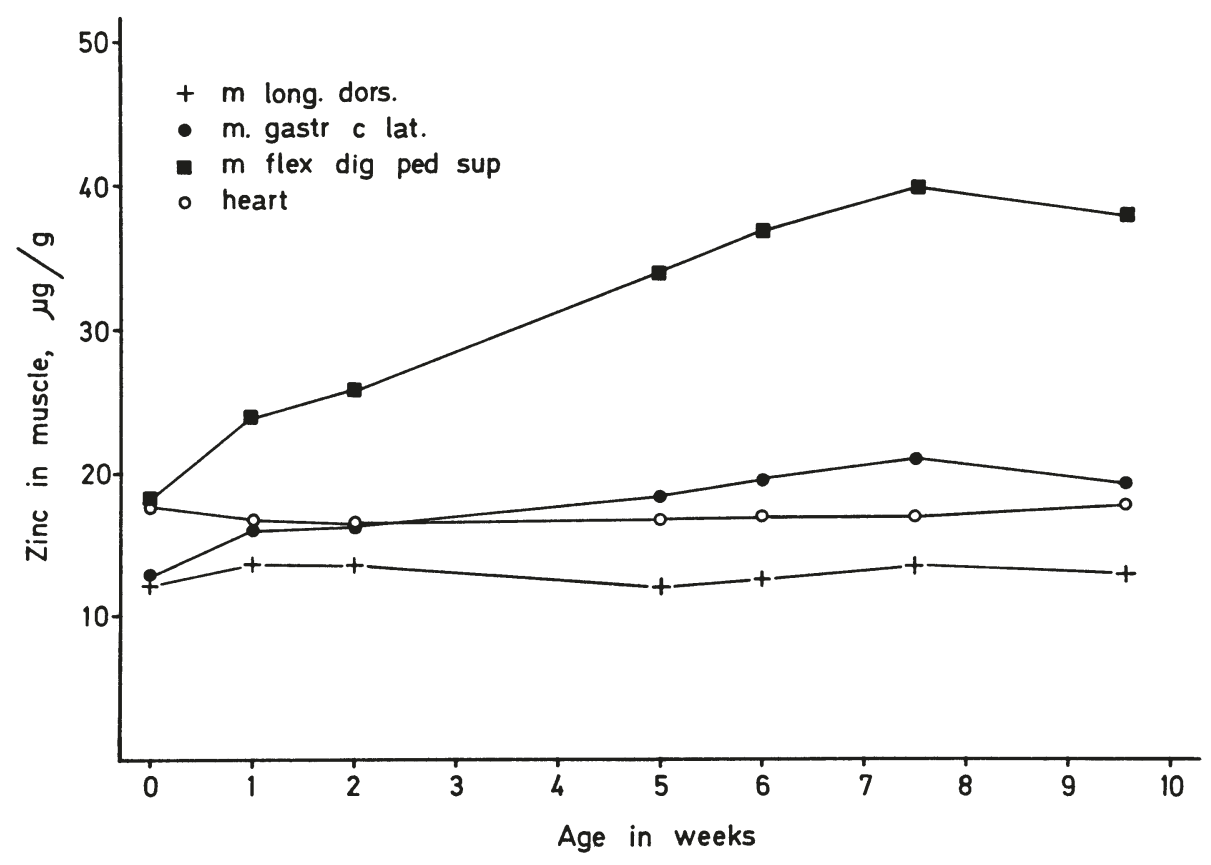

Figure 2. Variations in zinc content from birth to weaning in 3 skeletal muscles and heart.

T a b l e 1. Myoglobin and zinc content in different muscles from iron deficient and normal pigs.

\begin{tabular}{|c|c|c|c|c|c|c|c|}
\hline \multirow{2}{*}{$\begin{array}{l}\text { Pig } \\
\text { no. }\end{array}$} & \multirow{2}{*}{$\begin{array}{l}\text { Iron } \\
\text { supple- } \\
\text { ment }\end{array}$} & \multicolumn{2}{|c|}{ M. longissimus dorsi } & \multicolumn{2}{|c|}{ M. flexor dig. ped. sup. } & \multicolumn{2}{|c|}{ Heart } \\
\hline & & $\begin{array}{c}\text { myoglobin } \\
\mathrm{mg} / \mathrm{g}\end{array}$ & $\begin{array}{l}z \operatorname{inc} \\
\mu \mathrm{g} / \mathrm{g}\end{array}$ & $\begin{array}{l}\text { myoglobin } \\
\mathrm{mg} / \mathrm{g}\end{array}$ & $\begin{array}{l}\text { zinc } \\
\mu \mathrm{g} / \mathrm{g}\end{array}$ & $\begin{array}{l}\text { myoglobin } \\
\mathrm{mg} / \mathrm{g}\end{array}$ & $\begin{array}{l}\text { zinc } \\
\mu \mathrm{g} / \mathrm{g}\end{array}$ \\
\hline $496 / 1$ & & 0.20 & 15.6 & 0.30 & 30.4 & 1.01 & 20.6 \\
\hline $496 / 8$ & - & 0.15 & 17.0 & 0.22 & 36.7 & 0.48 & 20.1 \\
\hline $496 / 3$ & & 0.20 & 17.4 & 0.90 & 42.3 & 1.86 & 22.5 \\
\hline $496 / 4$ & + & 0.18 & 12.9 & 0.53 & 42.0 & 1.38 & 21.8 \\
\hline $496 / 7$ & & 0.33 & 16.5 & 0.94 & 54.7 & 1.50 & 20.8 \\
\hline
\end{tabular}

pigs (Table 1). While the myoglobin content, as expected, was decreased due to anaemia no significant decline could be detected in the zinc concentration in muscle tissue. Thus, there is apparently no functional link between myoglobin synthesis and zinc metabolism, although such linkage could have been expected 
considering the fundamental importance of zinc for enzyme sysitems connected with as well protein synthesis as energy metabolism.

\section{ACKNOWLEDGEMENT}

The authors wish to express their gratitude to Johs. Moustgaard, Professor, Dr. med. vet., for giving the inspiration to undertake this study and for fruitful discussions during the work.

\section{REFERENCES}

Cassens, R. G., E. J. Briskey \& W. G. Hoekstra: Variation in zinc content and other properties of various porcine muscles. J. Sci. Food Agric. 1963, 14, 427-432.

Cassens, R. G., W. G. Hoekstra, E. C. Faltin \& E. J. Briskey: Zinc content and subcellular distribution in red vs. white porcine skeletal muscle. Amer. J. Physiol. 1967, 212, 688-692.

de Duve, C.: A spectrophotometric method for the simultaneous determination of myoglobin and hemoglobin in extracts of human muscle. Acta chem. scand. 1948, 2, 264-289.

Henry, W. E. \& L. J. Bratzler: Effect of mineral supplementation on pork muscle color as measured by spectrophotometry and disk colorimetry. J. Animal Sci. 1960, 19, 1195-1203.

Kristiansen, P. H., I. Hфrup Pedersen \& I. Wegger: Zinkomsætningen hos svin. I. Vurdering af svinenes zinkstatus ved blod-, hår-og leveranalyser. (Zinc metabolism in swine I. Assessment of zinc status in pigs by analysis of blood, hair and liver). Kgl. Vet.og Landbohøjsk., Inst. Sterilitetsforsk. Aarsberetn. 1971, 14, 111-126. Copenhagen.

Miller, W. J., D. M. Blackmon, R. P. Gentry, W. J. Pitts \& G. W. Powell: Absorption, excretion and retention of orally administered zinc-65 in various tissues of zinc-deficient and normal goats and calves. J. Nutr. 1967, 92, 71-78.

Miller, W. J., D. M. Blackmon, R. P. Gentry \& F. M. Pate: ${ }^{65}$ Zinc distribution in various tissues of zinc-deficient and normal bull calves with time after single intravenous or oral dosing. J. Animal Sci. 1970, 31, 149-156.

Sandow, A. \& S. M. Bien: Blockade or neuromuscular transmission by zinc. Nature (Lond.) 1962, 193, 689—690.

\section{SAMMENDRAG}

Sammenhængen mellem zink og myoglobin $i$ muskler fra svin.

Zink- og myoglobinindhold i muskler fra svin blev bestemt under forskellige betingelser. Zinkkoncentrationen var betydelig højere i røde end i hvide muskler. I muskler, hvis stofskiftetype i perioden fra fødsel til fravænning ændres fra glykolytisk til oxydativ, sås sam- 
tidig en stigning i zinkkoncentrationen. Under normale betingelser er der en signifikant positiv korrelation mellem myoglobin- og zinkindhold. I forbindelse med jernmangelanæmi ses et fald i myoglobinkoncentrationen, hvorimod zinkindholdet ikke ændres. Der synes således ikke at være nogen funktionel forbindelse mellem zinkomsætning og myoglobinsyntese i muskler hos svin.

(Received February 20, 1976).

Reprints may be requested from: The Department of Physiology, Endocrinology and Bloodgrouping, Royal Veterinary and Agricultural University, Bülowsvej 13, DK-1870 Copenhagen V, Denmark. 